\title{
Medication use and polypharmacy in patients referred to a tertiary gastroenterology practice
}

\author{
ABIMBOLA CHRIS-OLAIYA ${ }^{1}$, WILLIAM PALMER ${ }^{2}$, FERNANDO STANCAMPIANO ${ }^{3 *}$, BRIAN LACY ${ }^{2}$, \\ MICHAEL HECKMAN ${ }^{4}$, RAZVAN CHIRILA ${ }^{3}$, NAVEED NIKPOUR ${ }^{5}$, ETHAN MCLEOD ${ }^{5}$, \\ TAYLOR RYAN $^{5}$, ALEX MAILLIS ${ }^{5}$, EMILY VARGAS $^{4}$, ERNEST BOURAS $^{2}$
}

\author{
${ }^{1}$ Department of Hepatology, University of Kentucky, USA \\ ${ }^{2}$ Division of Gastroenterology, Mayo Clinic Florida, USA \\ ${ }^{3}$ Department of Medicine, Mayo Clinic Florida, USA \\ ${ }^{4}$ Division of Biomedical Statistics and Informatics, Mayo Clinic Florida, USA \\ ${ }^{5}$ Mayo Clinic Florida, Clinical Research Internship Study Program, USA
}

\begin{abstract}
Introduction. Commonly prescribed medications are associated with various gastrointestinal (GI) side effects but few data are available on prescription medication use and polypharmacy in a gastroenterology outpatient practice. We aimed to examine the prevalence of polypharmacy, defined as the simultaneous use of 5 or more medications.

Methods. A descriptive correlational study of consecutive outpatient consultations in 988 patients referred to a tertiary gastroenterology practice. Main outcome measurements were frequency of prescription medication use and polypharmacy.

Results. The most common GI symptoms were abdominal pain (72\%), nausea $(57 \%)$, and constipation $(53 \%)$. The frequency of polypharmacy was $10 \%$. Eighty percent of patients took at least one medication and $60 \%$ took two or more. The most frequently used medication classes were proton pump inhibitors (43\%), followed by benzodiazepines (30\%), selective serotonin-reuptake or norepinephrine-reuptake inhibitors $(28 \%)$, non-steroidal anti-inflammatory drugs $(27 \%)$, and opioids $(21 \%)$.

Conclusion. There was a higher use of prescription medicine including antidepressants, and a lower frequency of polypharmacy in our study cohort compared to the general population. The use of medications may have contributed to the symptoms leading to our study's population GI consultation.
\end{abstract}

Key words: adverse effects, gastrointestinal, polypharmacy, prescription medicine.

\section{INTRODUCTION}

Polypharmacy and its risks have been extensively studied in the elderly population, but limited data are available on its prevalence in patients referred to tertiary centers and its association with disease clusters. Adverse drug reactions, drug-drug interactions, and drug-disease interactions are common undesirable consequences of polypharmacy that may confound clinical presentations $[1,2]$.

Despite the availability of evidence on the association between different classes of medication and GI disorders, there are limited data on polypharmacy in patients referred to tertiary centers and how the pattern of medication use affects presentation.

Aim of the study: To describe the prevalence of polypharmacy and the prevalence of certain medications in patients referred to a tertiary gastroenterology practice. Polypharmacy was defined as the simultaneous use of 5 or more medications whether prescribed or obtained over-the-counter at the time of gastroenterology consultation.

\section{MATERIAL AND METHODS}

Informed consent: Informed consent for this study was waived by the Institutional Review Board.

Ethical Approval: The research related to human use complied with all the relevant national regulations, institutional policies, and in accordance to the tenets of the Helsinki Declaration, has been approved by the authors' Institutional Review Board.

Study subjects: Data were collected retrospectively on 988 patients seen in consultation by gastroenterologists of different subspecialty interests from January 1, 2012 to December 31, 2016. Information regarding patient characteristics was collected for age, sex, race, body mass index (BMI), alcohol use, smoking, consulting gastroenterologist, and presenting GI symptoms (abdominal pain, nausea, vomiting, bloating/distention, diarrhea, and constipation). Prior diagnosis of gastroparesis was also recorded. We recorded whether patients were taking medications in various classes or groups. Classes of medications included PPIs (proton pump inhibitors), benzodiazepines, 
SSRIs/SNRIs (serotonin-norepinephrine reuptake inhibitors), opioids, non-steroidal anti-inflammatory agents (NSAIDs), dopamine agonists, tricyclic antidepressants. Medication groups included antiepileptic drugs (AEDs), central nervous system (CNS) stimulants, antihistamines, antihyperglycemic agents, antipsychotics, and supplements (iron and magnesium). If a patient was taking a medication in one of the aforementioned categories, the specific type(s) of medication and dose information were also collected.

The research was compliant with all relevant national regulations and institutional policies and has been approved by the Institutional Review Board.

\section{STATISTICAL ANALYSIS}

Continuous variables were summarized with the sample median and range. Categorical variables were summarized with number and percentage of patients. Age and BMI were the only continuous variables while the rest were categorical variables. For medication, in addition to estimating the percentage of patients who were taking each type of medication, we also estimated $95 \%$ confidence intervals for these percentages. Statistical analyses were performed using SAS (version 9.4; SAS Institute, Inc., Cary, North Carolina).

\section{RESULTS}

A summary of patient demographic and clinical information is provided in Table 1 . The median age was 53 years (range: 15-95 years), and the majority of patients were female $(74 \%)$, and white $(90 \%)$. The median BMI was $26 \mathrm{~kg} / \mathrm{m}^{2}$ (Range: 13-58). The most common presenting GI symptoms were abdominal pain (72\%), nausea (57\%), and constipation $(52 \%) ; 82 \%$ of patients presented with two or more GI symptoms. The median number of allergies reported was 1 (Range: 0-30). Overall, 806 patients $(82 \%, 95 \%$ CI: $79 \%-84 \%)$ were taking at least one medication at the time of their GI consultation. More specifically, 231 patients $(23 \%)$ were taking one medication, 218 (24\%) were taking two, 148 $(16 \%)$ were taking three, $106(11 \%)$ were taking four, and the remaining 103 patients $(10 \%)$ were taking five or more medications.

Table 1

Patient demographics and clinical information

\begin{tabular}{|c|c|}
\hline & Summary $(\mathrm{N}=988)$ \\
\hline Age & $53(15,95)$ \\
\hline Female & $730(73.9 \%)$ \\
\hline \multicolumn{2}{|l|}{ Race } \\
\hline Caucasian & $873(89.8 \%)$ \\
\hline African American & $73(7.5 \%)$ \\
\hline American Indian/Alaskan Native & $5(0.5 \%)$ \\
\hline Asian/Hawaiian/Pacific Islander & $11(1.1 \%)$ \\
\hline Other & $10(1.0 \%)$ \\
\hline BMI & $26.1(12.9,58.4)$ \\
\hline Current alcohol use & $392(45.4 \%)$ \\
\hline Current smoker & $93(9.8 \%)$ \\
\hline \multicolumn{2}{|l|}{ Presenting symptom(s) } \\
\hline Abdominal Pain & $715(72.4 \%)$ \\
\hline Nausea & $565(57.2 \%)$ \\
\hline Constipation & $519(52.5 \%)$ \\
\hline Diarrhea & $383(38.7 \%)$ \\
\hline Bloating/Distension & $349(35.3 \%)$ \\
\hline Vomiting & $300(30.3 \%)$ \\
\hline \multicolumn{2}{|l|}{ Total number of presenting symptoms } \\
\hline 1 & $177(17.9 \%)$ \\
\hline 2 & $241(24.4 \%)$ \\
\hline 3 & $273(27.6 \%)$ \\
\hline 4 & $165(16.7 \%)$ \\
\hline$\geq 5$ & $203(20.5 \%)$ \\
\hline \multicolumn{2}{|c|}{ Total number of different medications currently taking } \\
\hline 0 & $182(18.4 \%)$ \\
\hline 1 & $231(23.4 \%)$ \\
\hline 2 & $218(22.1 \%)$ \\
\hline 3 & $148(15.0 \%)$ \\
\hline 4 & $106(10.7 \%)$ \\
\hline$\geq 5$ & $103(10.4 \%)$ \\
\hline
\end{tabular}

The sample median (minimum, maximum) is given for continuous variables. Information was unavailable regarding race $(\mathrm{N}=16)$, current alcohol use $(\mathrm{N}=124)$, current smoker $(\mathrm{N}=37)$, and BMI $(\mathrm{N}=13)$. 
Table 2 displays the frequencies of patient medication use for different categories of medications and specific medication types within the given category. The most frequently used category of medications was PPIs (43\%), followed by benzodiazepines (30\%),
SSRIs/SNRIs (28\%), NSAIDs (27\%), opioids (21\%), AEDs (10\%), antihyperglycemic agents $(9 \%)$, and magnesium (6\%). TCAs, CNS stimulants, iron, antihistamines, antipsychotics, and dopamine agonists were used by less than $5 \%$ of the patients.

Table 2

Frequency of selected medication use.

\begin{tabular}{|l|c|c|}
\hline \multicolumn{1}{|c|}{ Medication } & Number (\%) of patients & $\mathbf{9 5 \%}$ confidence interval \\
\hline Proton pump inhibitors & $427(43.2 \%)$ & $40.1 \%-46.3 \%$ \\
\hline Benzodiazepines & $292(29.6 \%)$ & $26.8 \%-32.5 \%$ \\
\hline SSRIs and SNRIs & $275(27.8 \%)$ & $25.0 \%-30.6 \%$ \\
\hline Nonsteroidal anti-inflammatory drugs & $264(26.7 \%)$ & $23.9 \%-29.5 \%$ \\
\hline Opioids & $205(20.7 \%)$ & $18.2 \%-23.3 \%$ \\
\hline Tricyclic Antidepressants & $49(5.0 \%)$ & $3.6 \%-6.3 \%$ \\
\hline
\end{tabular}

\section{DISCUSSION}

Although universally recognized as having a major impact on a patient's health, polypharmacy has been defined in multiple different ways. Variables that lead to the diagnosis of polypharmacy include not only the number of medications, but also the duration of therapy, appropriateness of the treatment, and comorbidities among others [17]. In our study, we used a numerical definition of polypharmacy (the use of 5 or more medications) that included drugs dispensed by prescriptions as well as over the-counter products.

An analysis of a nationally representative survey showed an increase use of prescription drugs among United States adults after adjusting for age distribution [3]. The same study also revealed an increase in the use of proton pump inhibitors (PPI), antidepressants (tricyclic antidepressants (TCAs) and selective serotonin reuptake inhibitors (SSRIs), narcotic analgesics, anticonvulsants, and antidiabetics. These commonly prescribed medications have been associated with a variety of GI side effects.

Of special significance, PPIs are the most commonly prescribed medications for digestive diseases [4]. PPI use has been linked to alterations of the small intestinal microbiome, by theoretically eliminating the protective acidic environment in the stomach [5]. It is also conceived that excess gas production from bacteria in the small intestine promotes the development of irritable bowel syndrome (IBS) [6]. Opioids inhibit normal bowel function leading to constipation, abdominal pain, bloating, nausea and vomiting, narcotic bowel syndrome, and esophageal motility disorders [7-9]. In the same fashion, opioids and antidepressants may alter intestinal transit time via mechanisms that include cholinergic antagonism and excess gut serotonin levels [9-11].
The results of this analysis showed a high frequency of prescription medication use amongst patients referred to a tertiary GI practice. The prevalence of prescription medication use was higher in our study population $(80 \%)$ compared to the American population (68\%) as estimated from the Rochester Epidemiology Project. However, the prevalence of polypharmacy was lower in our study group (10\% versus $21 \%$ ) [12]. The prevalence of antidepressant use (33\%) [SSRI-28\%, TCA-5\%] was higher than the national average of $10 \%$ from the same study.

The negative consequence of polypharmacy in the elderly population has been the subject of research, but few studies have examined the subject within specific disease clusters [13-15]. To our knowledge, this is the first study evaluating prescription medication use, polypharmacy, and GI complaints in patients referred to a tertiary gastroenterology practice. In a similar study done in an outpatient endocrinology practice amongst 95 diabetic patients with nonalcoholic fatty liver disease, the authors found a high prevalence of polypharmacy (59\% taking 5-9 medications and 31\% more than 10 medications) [15]. After excluding cardiovascular and hypoglycemic medications, the most commonly prescribed medication was PPIs (43\%) as it was in our study. However, the prevalence of NSAIDs (3\%), SSRIs (15\%), benzodiazepines $(6 \%)$, and opioids $(12 \%)$ were lower compared to our findings. Their smaller sample size, narrower range of GI disorder, predominantly male population, higher rate of obesity, and older population could explain the differences between the two studies. We also realize that psychiatric disease may be associated with gastrointestinal complaints, but establishing a correlation between the reported symptoms and the psychological profile of the population was beyond the scope of our analysis. 
A more holistic approach to assessing polypharmacy within specific disease clusters and exploring how drug-drug interactions and drugdisease interactions affect disease presentation is the future of polypharmacy research [1]. The only published research in this area was a population study aimed at determining the specific interactions and synergistic effects between combinations of medications [16]. This primary care pharmacy database analysis identified disease clusters and examined the common medications used in each cluster, frequency of polypharmacy, and attempted to hypothesize causal relations. Finally, as some of the symptoms of gastrointestinal disorders may also be caused by medications commonly used to treat GI disease, primary care providers should consider making a numerical and/or non-numerical assessment of polypharmacy and requesting the assistance of a pharmacist prior to subspecialty medical consultation [18].

\section{LIMITATIONS}

Our study has several limitations. There was lack of data on the chronicity and frequency of medication use. As a result, it was difficult to establish the temporal relationship between medication use and the onset of GI symptoms, and therefore causality. Also, the presenting GI symptoms were reported by the patients, and not standardized. Furthermore, due to the retrospective design and the corresponding lack of systematic data entry, it is possible that the use of certain medications was not recorded for some patients, which means that the frequencies of medication use reported herein could be biased slightly too low. We did not report data on the volume or frequency of alcohol consumed by the study subjects. The findings in our study are only applicable to the patient population in an outpatient tertiary GI clinic and may not apply to the general population.

\section{CONCLUSION}

In conclusion, we found a high frequency of prescription medication use, but lower prevalence of polypharmacy amongst patients referred to a tertiary gastroenterology practice. Further studies are needed to explore possible associations between polypharmacy and disease-clusters in patients with GI symptoms.

Introducere. Majoritatea medicamentelor prescrise în mod uzual se asociază cu efecte adverse de natură gastrointestinală (GI) şi există puţine date în literatură despre aceste aspecte.

Metode. A fost realizat un studiu descriptiv pe 988 de pacienţi care se prezintă la un centru terţiar de ingrijire gastrointestinală. Efectele urmărite au fost frecvenţa prescripţiilor medicale şi polimedicaţia.

Rezultate. Cele mai frecvente simptome GI au fost durerea abdominală (72\%), urmată de greaţă $(57 \%)$ şi constipaţie (53\%). Frecvenţa polimedicaţiei a fost de $10 \% .8 \%$ dintre pacienţi au luat cel puţin un medicament şi $60 \%$ au luat două sau mai multe medicamente. Cea mai frecventă clasă de medicamente prescrisă ce a dus la consultaţia GI au fost inhibitorii de pompă de protoni (43\%) urmată de benzodiazepine (30\%), antidepresive (28\%), AINS (27\%), opioide (21\%).

Concluzii. Se administrează frecvent antidepresive, cu o frecvenţă mai mare faţă de populaţia generală. Polimedicaţia ar putea contribui la simptomele care se asociază cu prezentarea la medic din cauza simptomatologiei GI.

Correspondence to: Fernando Stancampiano MD, 4500 S San Pablo Road, 32224, Jacksonville, Florida, USA

Phone: +19049530659

Fax: +19049530655

E-mail: Stancampiano.F@mayo.edu

Funding: No funding provided.

Conflicts of interest disclosure: The authors declare that there are no conflicts of interest

Ethics approval: Approved the Institutional Review Board 
Consent to participate: waiver obtained

Consent for publication: granted

Availability of data and material: available on institutional secure servers

Code availability: $n / a$

\section{REFERENCES}

1. TINETTI ME, BOGARDUS ST, AGOSTINI JV. Potential pitfalls of disease-specific guidelines for patients with multiple conditions. N Engl J Med. 2004; 351(27):2870-2874.

2. GANDHI TK, WEINGART SN, BORUS J, SEGER AC, PETERSON J, BURDICK E, et al. Adverse drug events in ambulatory care. N Engl J Med. 2003; 348(16):1556-1564.

3. KANTOR ED, REHM CD, HAAS JS, CHAN AT, GIOVANUCCI EL. Trends in prescription drug use among adults in the United States from 1999-2012. Jama. 2015; 314(17):1818-1831.

4. EVERHART JE, RUHL CE. Burden of digestive diseases in the United States part I: overall and upper gastrointestinal diseases. Gastroenterology. 2009; 136(2):376-386.

5. IMHANN F, BONDER MJ, VILA AV, FU J, MUJAGIC Z, VORK L, et al. Proton pump inhibitors affect the gut microbiome. Gut. 2016; 65(5):740-748.

6. SPIEGEL BM, CHEY WD, CHANG L. Bacterial overgrowth and irritable bowel syndrome: unifying hypothesis or a spurious consequence of proton pump inhibitors? Am J Gastroenterol. 2008; 103(12):2972-2976.

7. HOLZER P. Treatment of opioid-induced gut dysfunction. Expert Opin Investig Drugs. 2007; 16(2):181-194.

8. LACY BE. Effects of Opioids on Esophageal Dysfunction. Gastroenterol Hepatol (N Y). 2016; 12(5):323-325.

9. CAMILLERI M, LEMBO A, KATZKA DA. Opioids in Gastroenterology: Treating Adverse Effects and Creating Therapeutic Benefits. Clin Gastroenterol Hepatol. 2017; 15(9):1338-1349.

10. CHIAL HJ, CAMILLERI M, BURTON D, THOMFORDE G, OLDEN KW, STEPHENS D. Selective effects of serotonergic psychoactive agents on gastrointestinal functions in health. Am J Physiol Gastrointest Liver Physiol. 2003; 284(1):G130-137.

11. HALPERT A, DALTON CB, DIAMANT NE, TONER BB, HU Y, MORRIS CB, et al. Clinical response to tricyclic antidepressants in functional bowel disorders is not related to dosage. Am J Gastroenterol. 2005; 100(3):664-671.

12. ZHONG W, MARADIT-KREMERS H, ST AUVER JL, YAWN BP, EBBERT JO, ROGER VL, et al. Age and sex patterns of drug prescribing in a defined American population. Mayo Clin Proc. 2013; 88(7):697-707.

13. FRANSSEN FM, SPRUIT MA, WOUTERS EF. Determinants of polypharmacy and compliance with GOLD guidelines in patients with chronic obstructive pulmonary disease. Int J Chron Obstruct Pulmon Dis. 2011; 6:493-501.

14. HOFFMAN F, VAN DES BUSSCHE H, WIESE B, SCHON G, KOLLER D, EISELE M, et al. Impact of geriatric comorbidity and polypharmacy on cholinesterase inhibitors prescribing in dementia. BMC Psychiatry. 2011; 11:190.

15. PATEL PJ, HAYWARD KL, RUDRA R, HORSFALL LU, HOSSAIN F, WILLIAMS S, et al. Multimorbidity and polypharmacy in diabetic patients with NAFLD: Implications for disease severity and management. Medicine (Baltimore). 2017; 96(26): e6761.

16. CALDERON-LARRANAGA A, GIMENO-FELIU LA, GONZALES-RUBIO F, POBLADOR-PLOU B, LAILA-SAN JOSE M, ABAD-DIEZ JM, et al. Polypharmacy patterns: unravelling systematic associations between prescribed medications. PLoS One. $2013 ; 8(12):$ e84967.

17. MASNOON A, SHAKIB S, KALISCH-ELLETT L, CAUGHEY GE. What is polypharmacy? A systematic review of definitions. BMC Geriatrics 2017; 17:230.

18. BEUSCART JB, PETIT S, GAUTIER S, WIERRE P, BALCAEN T, LEFEBVRE JM, et al. Polypharmacy in older patients: identifying the need for support by a community pharmacist. BMC Geriatrics 2019; 19(1):277.

Received $20^{\text {th }}$ May 2020 